\title{
WHAT CAN THE MYTHICAL FROG TELL US? THE SYMBOLISM AND ROLE OF THE FROG IN HISTORY AND MODERNITY
}

\author{
Jelka Vince Pallua \\ Institute of Social Sciences Ivo Pilar \\ Croatia \\ Email:jelka.vince@pilar.hr
}

\begin{abstract}
Frogs have always been related to the mythical origin of life. In mythologies throughout the world, frogs were associated with the primeval waters out of which life arose. The author looks at the rich symbolic language of this amphibian, with a special focus on its clear female symbolism - fertility, fecundity, female genitals, abundance, regeneration, renewal of life, pregnancy, eroticism, wetness/life, etc., as well as divine symbolism as revealed in the Polish and Croatian words for frog-boginka and bogina (goddess). The author identifies and discusses past and contemporary imagery, legends, narratives, and fairy-tales, and the folkloristic, mythical, ethnological, archaeological, and linguistic aspects of frogs and their symbolism. The folkloristic triplet toads - babas - mushrooms identified during the research is presented as additional proof of the analogous linguistic triplet with bau or bo roots in some European languages. All three of the items, with the aspect of wetness as a precondition for fertility, as shown in the paper, are symbols of female sexual organs, fertility, and renewal. In the end, the author points to the longevity of the image of the frog presented next to the Virgin Mary in an interesting syncretism of the pre-Christian and Christian worlds.
\end{abstract}

Keywords: female genitals, fertility, frog, frog-goddess, frog-woman, frog-womb votives, regeneration, toad, Virgin Mary

Frogs have always been related to the mythical origin of life. In mythologies throughout the world they were associated with the primeval waters out of which life arose. In this paper, I will try to enter into the rich symbolic language of this amphibian, with a special focus on its evident female symbolism - lunar attributes, fertility, fecundity, abundance, regeneration, renewal of life and resurrection, pregnancy, the womb, eroticism, wetness/life, bringer of rain, protector of mothers and newborns, protector of water springs, etc. It is clear that the regenerative symbolism not only of fish, but of frogs as well, comes from their aquatic environment. Frogs, associated with the primeval waters, 
were the symbol of the life-giving uterus with its water-like amniotic fluid. Therefore, one of the many terrestrial guises of the Great Goddess/Mother Goddess, the great regeneratrix, was the image of a frog (Gimbutas 1999; Kuğutjak 2018: 156). In her latest book, Ten Gods, Emily Lyle specifically states that "[a] point of special interest, since it contradicts some current understandings of the Indo-Europeans, is that the approach taken here seems to show that in prehistory goddesses played central, though not dominant, roles within the pantheon" (Lyle 2012: 115). By providing several examples of historical and more contemporary imagery, some of which are perceived as such for the first time, it will be shown that frogs themselves were considered procreative organs.

The aim of this paper is not to discuss or back up the "Goddess theory" and its scientific or historical accuracy, but to use historical and contemporary imagery and narratives and the folkloristic, ethnological, archaeological and linguistic aspects of the frog and its symbolism as new evidence and support for Marija Gimbutas' position that "more recent beliefs concerning frogs and toads illuminate those of prehistory" (Gimbutas 2001 [1989]: 251) and that "many images and beliefs about frogs and toads endured through the Bronze and Iron Ages and in European folklore and folk art" (Gimbutas 1999: 30). ${ }^{1}$ It should be noted that although there are several illustrative examples from other regions given as references, the principal region under study is Croatia.

\section{VOTIVES}

Let me first focus on votives/ex-votos and amulets in the shape of a womanfrog or a womb. These objects have been known from prehistoric times until the present. It is the most striking example of the continuity of pre-Christian traditions connected with the motif of the frog, which, as already mentioned, is considered a symbol of fecundity and fertility - a renewal of life. In contemporary Europe, including in Croatia, peasants believe that a frog or a toad ${ }^{2}$ is a portent of pregnancy. "Both Hippocrates and Plato described the uterus as an animal capable of moving in all directions in the abdomen" (Gimbutas 2001 [1989]: 251). In the Tyrol region of Austria, as testified in folk beliefs recorded at the beginning of the twentieth century, people believed that women had something similar to frogs in their wombs (Kus-Nikolajev 1928: 39). There is also a close symbolic relationship between the toad and the female body.

In a vast area of western Europe from Alsace to the Tyrolean Alps, phenomena of spirit possession resulted from a toad's bite or its penetration into the body of the possessed (Charuty 1997: 82-94).... The identification of the 'bite' with the uterus was based on an age-old representation of 
the female sex organ, which, according to a tradition running through Greco-Roman, Renaissance, and Baroque medicine, was endowed with a mobility that made it similar to an animal, and in this form it 'possessed' the female body. (Pizza 2006: 1124)

A visible association of the toad with the vagina can clearly be seen in a wax toad ex-voto from Germany (Fig. 1).

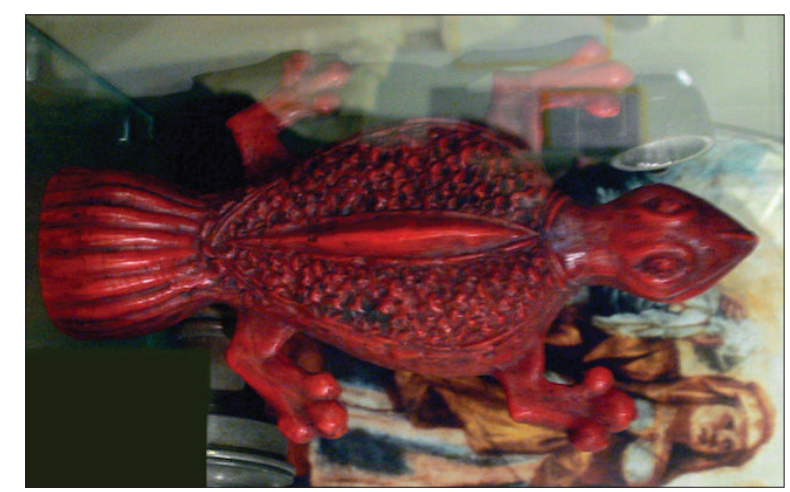

Figure 1. German wax toad votive with a vulva on its back (see https: / / www. atlasobscura.com / articles / toad-votives-religion-medieval-saints, last accessed on 4 November 2019).

Furthermore, small toad sculptures and votives were placed as offerings at Christian holy sites or were brought to the shrines of certain saints as a petition for pregnancy. A certain logic is evident in this offering, since toads were sometimes considered vaginal symbols in the medieval mind. In addition to their association with childbirth, toads (like vaginas) were also linked to sin, magic and evil ${ }^{3}$ (Laskow 2017).

In Croatia, people also used to buy votives in the shape of a woman-frog or a womb, as a votive for the protection of female genitals as a prayer for conception and pregnancy. They were bought from licitar makers (licitar is a traditional, colourfully decorated biscuit) and were brought to church as votive gifts and left there with the faith that their prayers would be answered. Frog-shaped licitars are still sold today by licitar makers in Marija Bistrica, one of the most famous Croatian pilgrimage sites, situated close to Zagreb. Its symbolic meaning has changed and today it is used to bring health to the whole family. It should be added that silver or golden ex-votos made in Dalmatian goldsmiths' workshops were owned by the wealthy upper classes, while wax votives were more common among the poorer classes in Croatia (cf. Grdinić \& Dugac \& Biškupić Bašić 2007: 37). ${ }^{4}$ 


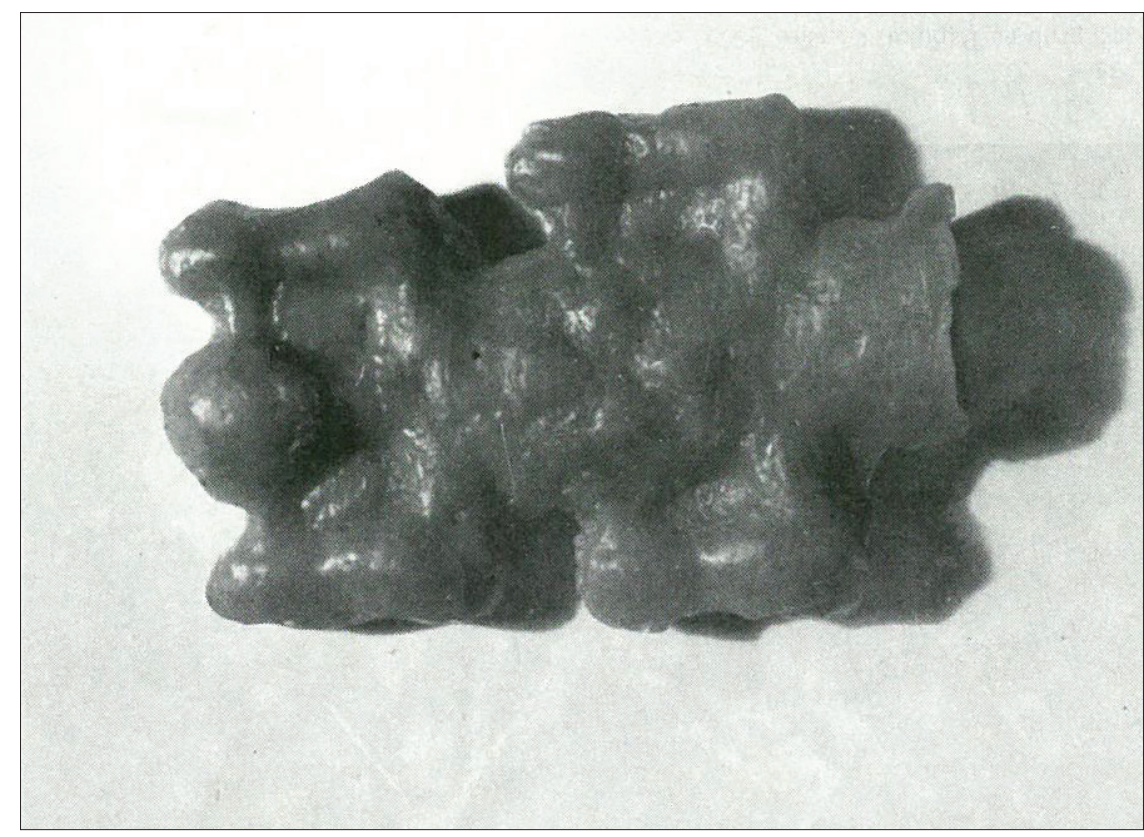

Figure 2. Infertile woman's wax žena-žaba (woman-frog), i.e. womb votive. Marija Bistrica, Croatia (Čulinović-Konstantinović 1989: 222).

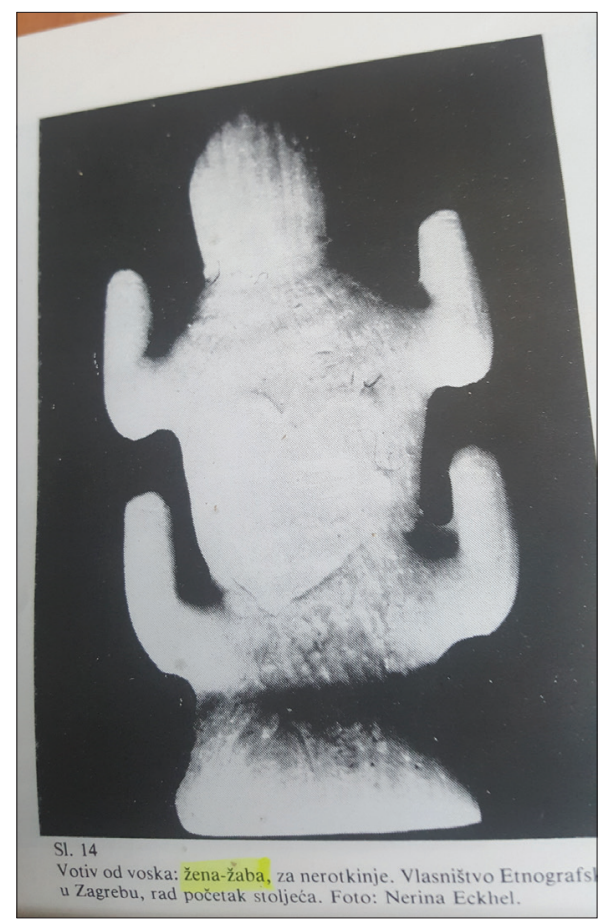

Figure 3. Infertile woman's wax žena-žaba (woman-frog) votive. Ethnographic Museum, Zagreb, Croatia, early 20th century (Čulinović-Konstantinović 1989: 222). 


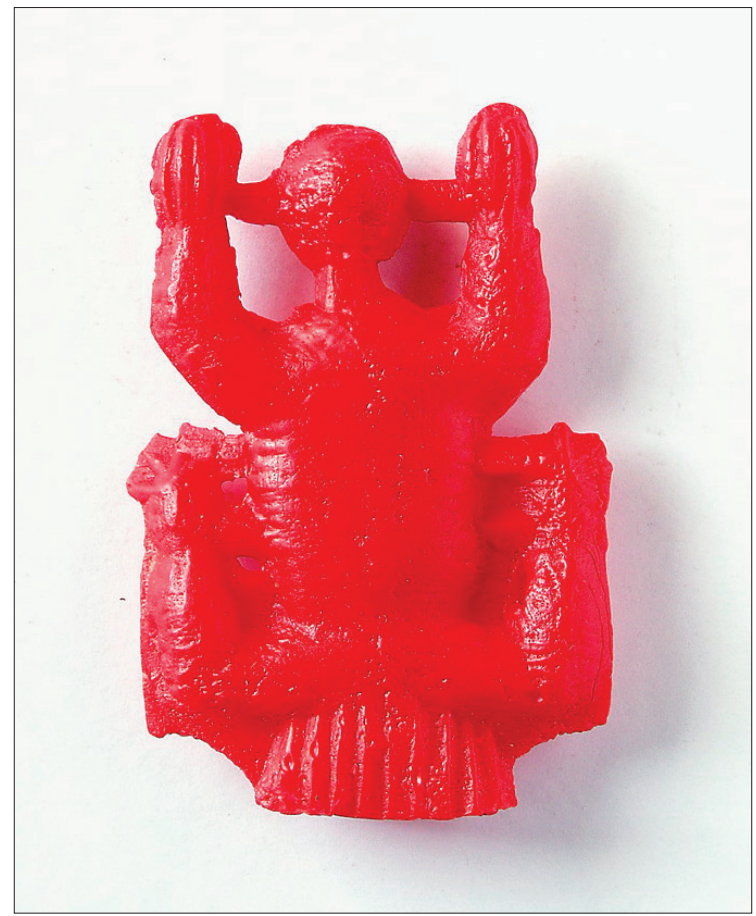

Figure 4. Wax votive in the shape of a womb (frog), votive gift for the protection of female genitals (Catalogue 2013: 92).

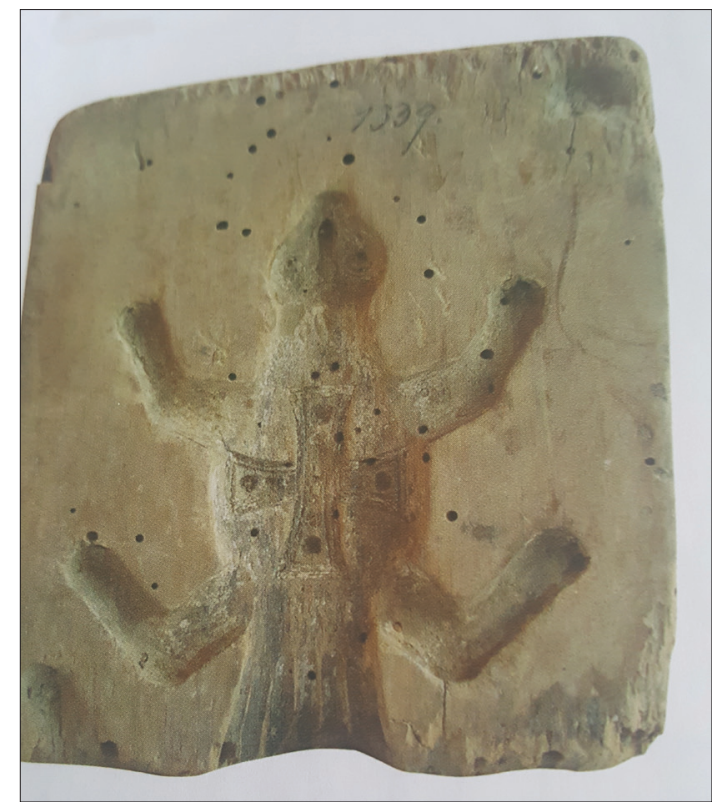

Figure 5. Mould for a votive - frog with a cross on its back. Križevci City Museum, northern Croatia, mid-19th century, wood (Grdinić \& Dugac \& Biškupić Bašić 2007: 8). 


\section{RITUAL FROG DANCES - ŽAPCI (CROATIA) AND ŽABSKÁ (MORAVIA, CZECH REPUBLIC)}

Let us move on to a quite amusing illustration of the frog as a symbol of fertility: the magical ritual dance called Žapci (Frogs), in which the movement of frogs is imitated, as the name itself suggests. It was performed until the $1970 \mathrm{~s}$ in the northern part of Croatia, in several villages close to Čazma, but also in southern Moravia in the Czech Republic, in Haná and in the Horňácko region.

The dance from northern Croatia was described in 1967 as follows: ${ }^{5}$

The ritual dance Žapci is still performed in only two or three villages around Čazma. ... At the end of winter, a few married couples meet in the evening in a large, well-closed room. After a short conversation and singing over drinks, the dance begins. At first everyone stands in a circle, couple next to couple, so that they face each other back to back. Then each dancer leans forward with arms extended nearly to the ground. When given the signal, everyone thrusts their head forward, swaying slightly left and right while beating their feet rhythmically and deeply mumbling $\mathrm{mm} \mathrm{mm}$ $\mathrm{mm}, \mathrm{mm} \mathrm{mm}$. When man and woman meet, the woman usually grabs the man's shoulder with her arms and jumps over him. She then comes upon the next player and jumps over him or her as well, or they jump over her. While jumping, they usually touch each other's genitals with their arms or heads. Nobody can say anything about the origin of this dance, and it is not openly talked about. It is mentioned only in secret circles, and they even secretly invite the dancers to the event. (Lovrenčević 1967: 155)

We can see that this ritual dance, performed by married couples in secrecy, where the genitals of the opposite sex are touched while imitating frog movements, is an obvious imitation of a sexual act, symbolising and evoking the fecundity of the annual agricultural cycle. But this does not only include the fertility of the fields: "The aim of this frog-dance is the evocation and intensifying of the overall fertility of the fields, the cattle and also the people of the village" (Lovrenčević 1967: 155).

The other ritual dance with a similar name derived from the word for frog is the Žabská or Žabsky, ${ }^{6}$ which is performed in Moravia, the south-eastern part of the Czech Republic. The dance is accompanied by lascivious songs called falický (phallic songs). This ritual dance, which also has visible elements of fertility magic, is performed by making various leaps in the squatting position. In this way, frogs' leaping, jumping and hopping is imitated in a humorous way. In the Horńácko region this dance was most often performed on certain saints' name days or during traditional carnival festivities accompanied by a specific 
song, which was not the same everywhere - Hrály dudy (The Bagpipes Played) or Žába leze, žáb za ní (A Frog is Crawling, and Another is Crawling After It) (Tyllner et al. 2007). Since the lascivious scenarios of both dances are similar, there is no doubt that the Czech name falicky is derived from the Latin word phallus. Clearly, both the Croatian and Czech ritual dances imitate the sexual act, serving as a magical ritual for fertility and fecundity for which the frog is a symbol. Additionally, it should be noted that the Croatian dance $\check{Z} a p c i$ is performed at the end of winter when the agrarian cycle is the weakest; therefore, it was necessary to supplicate for its fertility through ritual. If we now recall the frog-womb votives (Fig. 2,3,4) offered as gifts by infertile women and compare them with the Croatian and Czech ritual dances Žapci and Žabská, it is clear that both Slavic "frog dances" have the same purpose - encouraging procreation and fertility.

As we have seen, both dances are performed in a squatting position. This typical frog position can well be compared with the folkloristic material from the Yaroslavl province in Russia, where in order to get married, spinsters had to find a frog and after squatting and jumping like a frog had to sit on it with their naked bottom (Gura 2005: 283). The examples presented here, as can be noticed, all come from Slavic ethnology.

\section{FROG NAMES FOR FEMALE GENITALS}

\section{Žabicu driti (to break a small frog)}

In the same context, it is highly interesting to examine several frog names that illustrate their evident linguistic and symbolic connection with the frog's main connotation - fertility. In some villages in Germany, women call the womb a toad (Devereux 1990: 72), so it can be seen that frog symbolism is also present outside the Slavic world. Moreover, in Yucatan, the same word (much) is used for both female genitals and frogs (Seler 1910: 81). I have found a similar linguistic phenomenon in Croatian, in the Istrian dialect (Fig. 6).

The Croatian word for frog is $\check{z} a b a$, and the diminutive form is $\check{z} a b i c a$. In a dictionary of local idioms from the village of Vodice in Istria, Croatia, I found quite an interesting syntagm, žabicu driti (to break a small frog) or, as this Croatian phrase was explained in German, Blut brechen ${ }^{7}$ (to break blood) (Ribarić 2002: 225). The German phrase Blut brechen consists of two common German words - blood and break. But what about the phrase in Croatian - żabicu driti (to break a small frog)? What does it indicate? There is no doubt the syntagm žabicu driti denotes an act of defloration, where $\check{z} a b i c a$ (a small frog) is again a term for women's genitals that bleed when they are "broken" during the first 


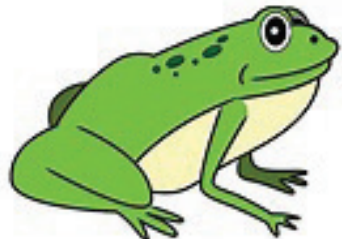

Žaba - a frog

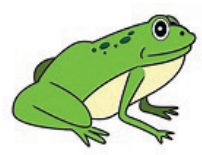

Žabica - a small frog

Žabicu driti / to break a small frog

Blut brechen / to break blood

Figure 6. The syntagm žabicu driti (to break a small frog).

sexual act. The explanation in German that Ribaric adds after the Croatian syntagm žabicu driti proves that a small frog, žabica, again represents the female sexual organ. ${ }^{8}$

\section{Žabica - a word for the triangular part of the Croatian national costume}

In the same territory of Istria in western Croatia, I found another indicative piece of evidence also connected with the diminutive form $\check{z} a b i c a$, this time as the name for the part of the traditional female Istrian costume described in a text written by Jelka Radauš Ribarić, expertly analysing the phenomenon of the socalled klinasto ruho (wedge-shaped costume). A žabica in the form of a triangle/ wedge is inserted at the back of the long dress, thus broadening its skirt (Radauš Ribaric 1997: 121). ${ }^{9}$ Not only do we once again find the same diminutive word $\check{z}$ abica, indicating female genitals, but this piece of cloth called $\check{z} a b i c a$ is placed exactly on the part of the dress where the female genitals are located. This žabica is also tailored in the shape of a triangle/wedge that is inserted into the bottom part of the dress called rubina in the shape of a double triangle, which even more clearly corresponds to

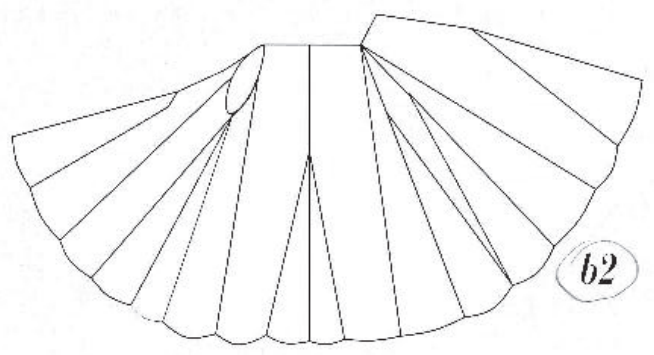
the anatomy of the female sexual organ.

Figure 7. Žabica, a triangle / wedge inserted into a wedge-shaped rubina (dress). Istria, Croatia (Radauš Ribarić 1997: 134 b2). 
Figure 8. Female genitals in triangular form. Lepenski vir, Serbia, 6000 - 5000 BC (front cover of Devereux's book Bauba - Mitska vulva, Zagreb, 1990).

Another part of the Croatian traditional costume with the name $\check{z} a b i c a$, also in the shape of a triangle, can be found in the village of Habjanovci in Slavonia, in the eastern part of Croatia. The description of the upper oplećak (shirt) informs us that there is a small triangular piece of canvas under the armpit called a žabica, which was supposed to prevent the stiches from breaking

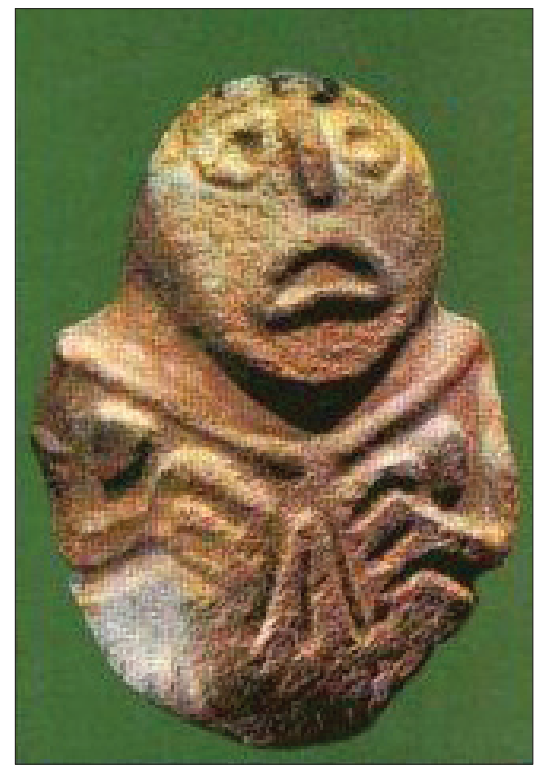
(Španiček 2010: 27). ${ }^{10}$ It should be emphasised that in both the Istrian and Slavonian cases, the part of the traditional national costume called žabica, inserted either into the long dress or under the armpit, is in the shape of a triangle. I believe that this ethnological element - a $\check{z} a b i c a$ as a triangular piece of cloth - can be associated with the triangles engraved on numerous prehistoric female statues where they also represent female genitals. Let me illustrate this claim with the image on the front cover of the Croatian translation of Georges Devereux's book Baubo, la vulve mythique, about the goddess Bauba.

As we have seen, the term $\check{z}$ abica, in both folkloristic as well as in the original linguistic examples presented and discussed above, has been identified in this paper as a synonym for female genitalia, as is the frog itself.

\section{LOVE MAGIC}

On the basis of the frog names given to female genitals discussed above, the female sexual symbolism of the frog can be clearly detected. Now let us turn to the use of the frog in love magic.

In Ukrainian Galicia a young man in the marsh catches a frog that is the first to make a croaking sound during sunset. He then inserts a needle and thread into the frog and uses the same needle to discreetly stick into the lower part of the skirt of the girl he is in love with. (Gura 2005: 283) 
A very similar theme of a young man's attempts to use a frog in love magic to win the heart of the girl he loves can be found in the legend "Tri dlake i zelena žaba" (The Three Hairs and the Green Frog) from Ćićarija in Istria, Croatia. In this story, a young man is hunting for a green frog in order to find a remedy for unrequited love:

When the young man finally found the green frog, he put it in a little box and poked a hole in it with a sharp piece of wood and placed the box on a large anthill. The ants immediately began to ravenously devour the green frog. After two whole days, the lovesick young man returned to the anthill and peeked into the box; inside he found a clean frog skeleton ... He went to mass on Sunday. As he was leaving the church, he met his love's gaze in the crowd. He managed to touch her with the box with the frog skeleton inside, as they were crowding around the holy water font, and he was certain that the power of the frog skeleton would work its magic. (Vrkić 1991: 188-189)

Let us recall the similar love magic mentioned above, i.e. the love-marriage magic testified to in the folkloristic material from Yaroslavl province in Russia, where, in order to get married, spinsters had to find a frog and after squatting and jumping like a frog had to sit on it with their naked bottom (Gura 2005: 283). From other magic uses it can be added that "a frog as a fairylike being plays an important role in folk medicine, and its demonic characteristics are most evident during childbirth. ... In order to protect women from these fairy beings, amulets containing their image (a frog) are used" (Kus-Nikolajev 1928: 41).

\section{A LINGUISTIC AND FOLKLORISTIC TRIPLET: TOADS - WITCHES (BABAS) - MUSHROOMS}

We now come to the interesting linguistic triplet toads ${ }^{11}$ - witches - mushrooms, which I have realized is a folkloristic triplet as well. Marija Gimbutas writes that "some European languages use the root bau or bo in association with names for toads, witches or mushrooms. ... I believe these words reflect the names of the goddess of death and regeneration before she was rendered a demon" (Gimbutas 1999: 29).

The etymological connection between the three terms is quite thought-provoking. I realized that my own ethnological research of the same three items, years before I read the paragraph above, had led me in the same not etymological but "mythological" direction. ${ }^{12}$

As stated above by Gimbutas (1999: 29), in some European languages the root bau or bo is associated with the words for witches, mushrooms, and toads. 
Baba also means "witch" in Bulgarian and Polish dialects (Alinei 1988: 43). On the other hand, in France, the words bo, bot, botet (in the Haut Saone and Loire provinces) mean "toad" (Gimbutas 1999: 29). "In Lithuania, bauba denotes a frightening witch or monster ... These could be related to the Lithuanian baba, an old woman or wife, and bobausis, an edible fungus" (Gimbutas 1999: 29, 218 (footnote 18)). It is similarly interesting that the German word Hexe signifies both "toad" and "witch". Likewise, in Italian dialects a frog is defined as strega (witch) or fata (fairy) (Pizza 2006: 1123), so they intertwine linguistically.

However, this interlacing is not merely linguistic. Narratives about the intertwining of frogs/toads and witches in folklore, i.e., about the transformation of a witch into a frog, are actually quite common. As one of many examples, let me quote one from eastern Slovenia, on the border with Croatia: “...the widespread conviction that it is the neighbours who bewitch [sic] obviously influenced the 'victim' to immediately connect the toad, in our region typically understood as an incarnation of a witch who comes to do harm, with her neighbour" (Mencej 2015: 115).

When neighbours saw a toad on the piece of land that was an object of dispute regarding the ownership, they obviously recognised the narrator with whom they were in conflict about this particular piece of land as the toad, i.e. the witch. (Mencej 2015: 123)

The transformation can also occur in the other direction (from toad to witch):

Sometimes a frog is nothing but a female person who turned into one.... In our country, people also believe that a witch turns into a frog. ... and a girl turned into a frog. In Lukovdol near Severin, a frog is perceived as a witch (coprnica). In Stupnik near Zagreb, people say that a toad is a coprnjica, a witch. In Čučerje near Zagreb, people believe that a frog (coprnica) can turn into a coprnica (witch). (Đorđević 1958: 197)

Apart from turning a toad into a witch, the negative and dark aspect of the toad is also evident, and toads are often considered to be opposites of frogs. There is also "an old story of a witch with a frog as her demonic companion evolved in the oral tradition to become 'The Frog King' (or 'The Frog Prince'), the first tale in the famous collection of German fairy tales by the Grimm brothers" (Sax 2001: 127).

Let us also illustrate this transformation with part of a fairy-tale from the Podravina region in Hungary, titled (in Croatian) "Krastača i ružica" (The Toad and the Rose).

There was an old woman, she had a beautiful granddaughter. The young girl was fifteen years old, and she knew that her grandmother was a witch 
... The grandmother told the granddaughter, 'Go to the well and look!' A crusty toad as big as a bread paddle was swimming inside. The young girl was very frightened. 'Don't worry,' said the grandmother, 'I used to be that crusty toad, and you used to be that beautiful rose on the water.''Grandmother, I love being the rose and not the witch'. (Vrkić 1991: 133)

What else makes this triplet so relevant? Besides the etymological connection of the three items presented above, there is another obvious bond connecting them. They all are connected with water and wetness, and they represent the same thing - the female genitalia and thus fertility and renewal. Therefore, let us now focus on the first two items - the baba and the mushroom.

\section{Monolithic babas}

The abovementioned root word $b a(u)$ can be found in the word for the monoliths (called babas) that I found during my fieldwork in the Adriatic part of northwestern Croatia in $1995 .{ }^{13}$ It should be remembered that in Croatian baba means "old woman" or "old hag", and as a mythological character a $b a b a$ is similar to a witch, one of the three items mentioned by Gimbutas. Babas, the rocks I discovered during my fieldwork on the island of Krk and in Istria, have to be offered fruit and wheat and have to be kissed when approached for the first time, often expressed in the form of a threat to children that they would have to kiss an old woman's behind.

When I began my research some twenty years ago, the baba was not understood as an aquatic goddess with water being one of her main connotations. It took me some time and effort to discover that these $b a b a$-monoliths were always associated with water in some form. Little by little I noticed that all babas were situated near water (by wells and streams) and that they were all accompanied by the legend about kissing the hag / ugly old woman and by the need to give her gifts of fruit, wheat, etc. Furthermore, the attributes wet, slimy, snotty, damp, and mucous undoubtedly also indicated the presence of water and humidity - the preconditions for fertility. The aquatic nature of all these babas is additionally confirmed by the hydronyms of the water bodies they are situated on (Potočina named after the Croatian word for stream (potok) and Pucunel after the Italian word for well (pozzo)).

I had to ask myself what these $b a b a$-stones personify, why they are kissed and given offerings, and what the meaning of the legends and practices was. After a while I found the most illustrative answer during my fieldwork, when I discovered the only figurative representation of the $b a b a$ at that time ${ }^{14}$ - the unique Grobnik Baba near Rijeka, which is not a rock shaped by nature but 
a grotesque female figure carved out of a solid rock, with a large head and emphasized feminine attributes - large hips and breasts (unfortunately diminished by the children's game of flinging pebbles) no doubt symbolizing fertility and abundance (Fig. 9, 10).

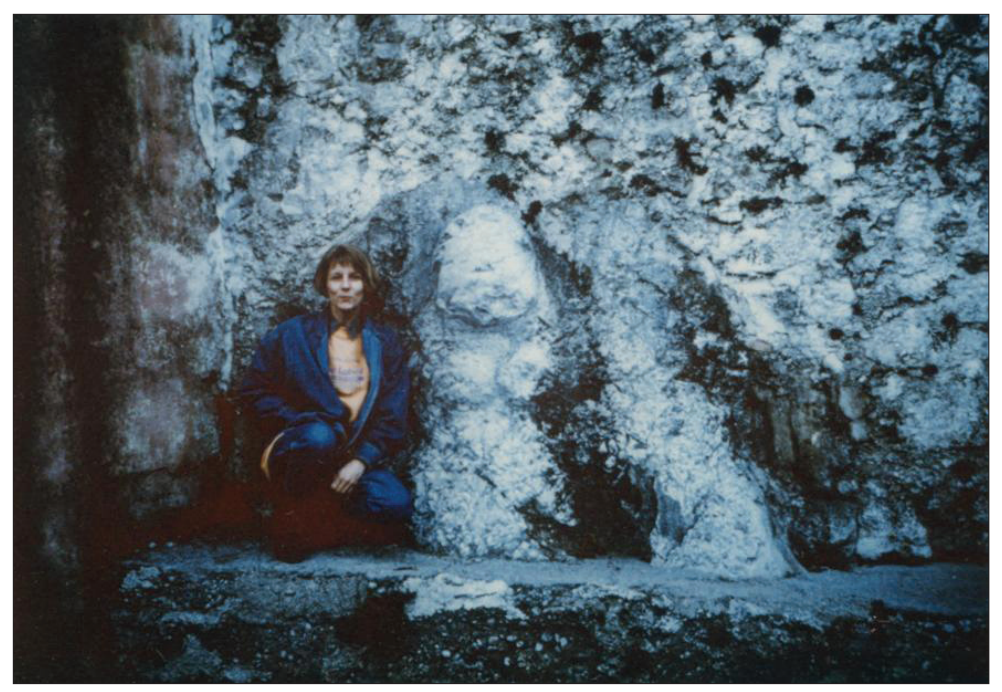

Figure 9. The Grobnik Baba. Photograph by the author 1996.

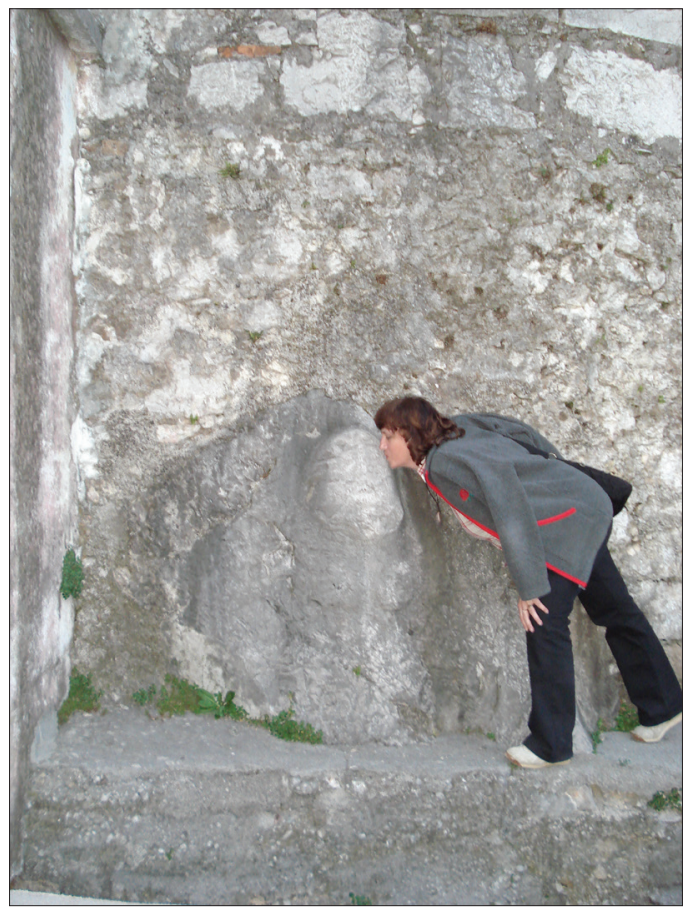

Figure 10. The Grobnik Baba. Photograph by Z. Novačić 1996. 
Like all the other amorphous babas, she is "snotty and muddy", as her wetness was described by the informants from the region, and is visible from the dark trail of water along the entire stone figure. The Grobnik Baba also had to be kissed and offered gifts when a stranger came to town for the first time. Hrobat (now Hrobat Virloget) continued to explore the "wet" aspect of the babas, paying particular attention to the connection of the element of water in the form of atmospheric elements with the baba's bodily fluids in the context of fertility (Hrobat 2010: 207-209).

At the end of this section, I should mention George Devereux's book Baubo, la vulve mythique (1983), in which the author presents the goddess Baubo/ Bauba who displays her vulva. Similarly, Hrobat (2010: 212) observes that both goddesses, Baubo and Baba, raise their skirts. This act is also present in the title of Hrobat's book from 2010. ${ }^{15}$ Now that we have addressed the monolithic babas, let us turn our attention to mushrooms picked by another baba.

\section{Mushrooms - "Baba Went Mushroom Picking”}

Like babas, mushrooms are closely connected with water, and in fact, mushrooms are largely composed of water. ${ }^{16}$ In this case, a baba is picking mushrooms in the woods - a wet, humid area. In the northern Međimurje region of Croatia, Baba exists as a character in the traditional wedding ritual comedy skit "Baba

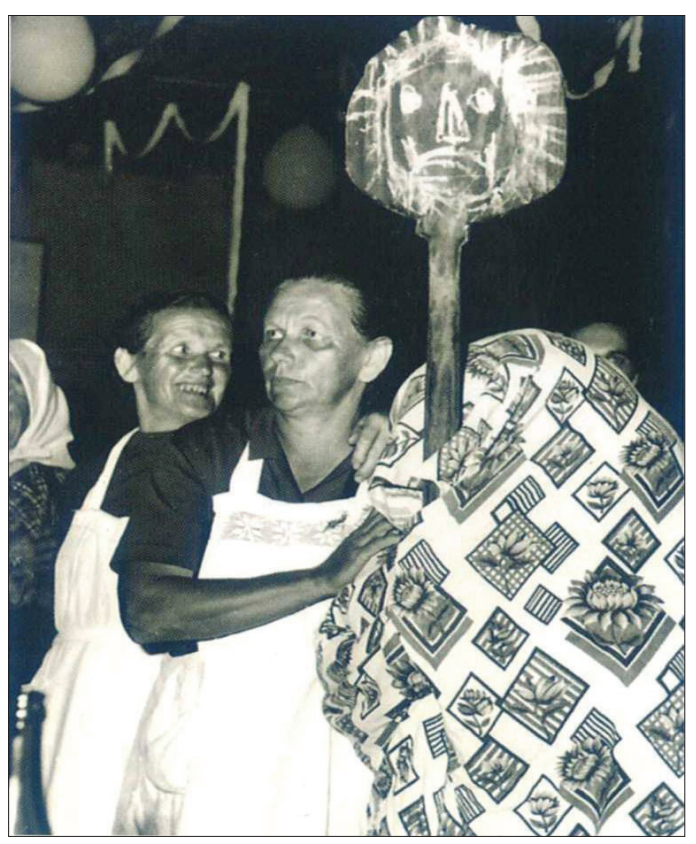

Went Mushroom Picking", where the motifs of baba and mushrooms are intertwined. The main character Baba is dressed as an old woman with grotesquely large hips and breasts (like the Grobnik Baba) filled with straw. She is holding a wooden bread paddle containing a chalk drawing of baba's wound, which is actually a depiction of female genitals, locally called cuca (Fig. 11, 12).

Figure 11. Traditional wedding ritual comedy skit "Baba Went Mushroom Picking”. Goričan, northern Croatia, 1975 (Hranjec 2011: 244). 
Figure 12. Traditional wedding ritual comedy skit "Baba Went Mushroom Picking”. Goričan, northern Croatia, 1975 (Hranjec 2011: 243).

The entire skit clearly emphasizes the symbolism of fertility and fecundity, as is otherwise common in wedding customs. In addition to the claimed aphrodisiac property of mushrooms, it is obvious that their shape resembles the congress of the male and female genitalia,

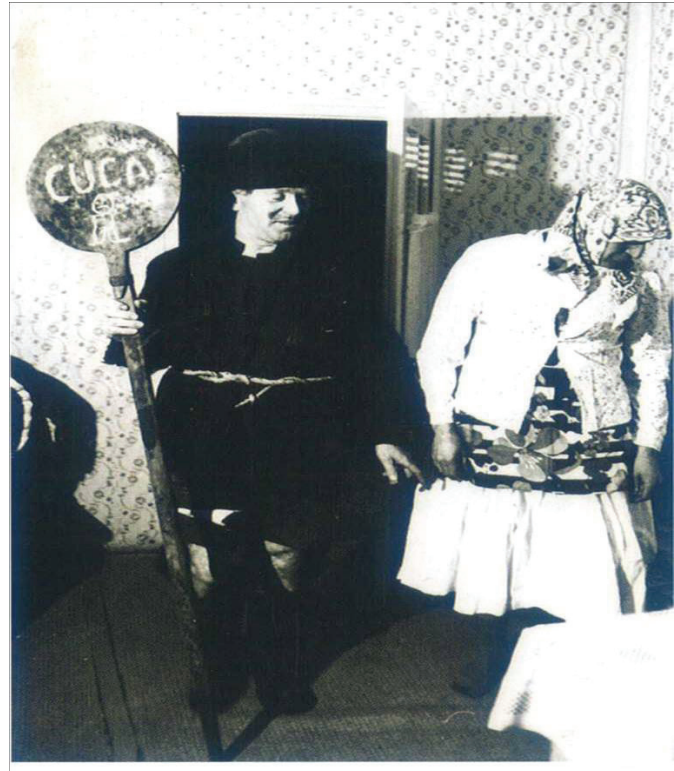
and that it symbolizes not only fertility but also the bond of marriage, happiness, and life force. In the wedding comedy "Baba Went Mushroom Picking", the obscenity of the gestures of Baba's escort, Djeda, and the free and lascivious dialogue between the wedding celebrants and Baba should be considered within the same context of the desire for fertility in marriage. The erotic symbolism of the wooden bread paddle with a drawing of Baba's "wound" (mentioned in the song called "Baba Went Mushroom Picking"), is also in the service of fecundity.

Moreover, mushroom-shaped pastries are served which also symbolize fertility, an important motif that we have already encountered a number of times (Fig. 13). ${ }^{17}$

Figure 13. Traditional mushroom wedding pastry (anonymous, taken in Dragoslavec-Breg, Croatia, 2012).

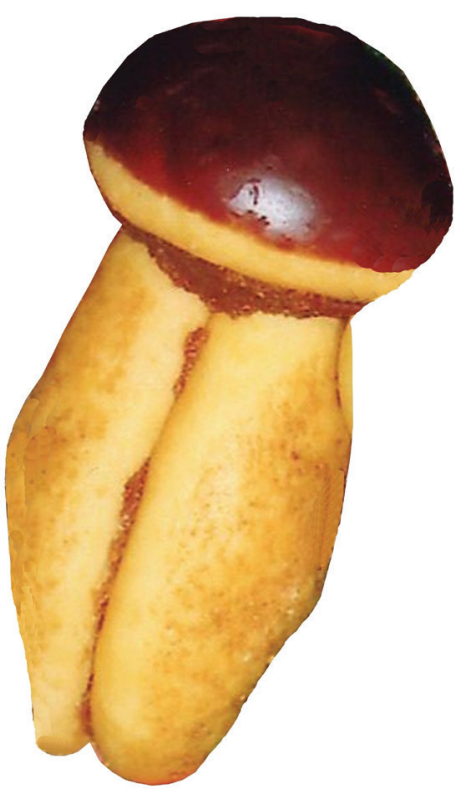




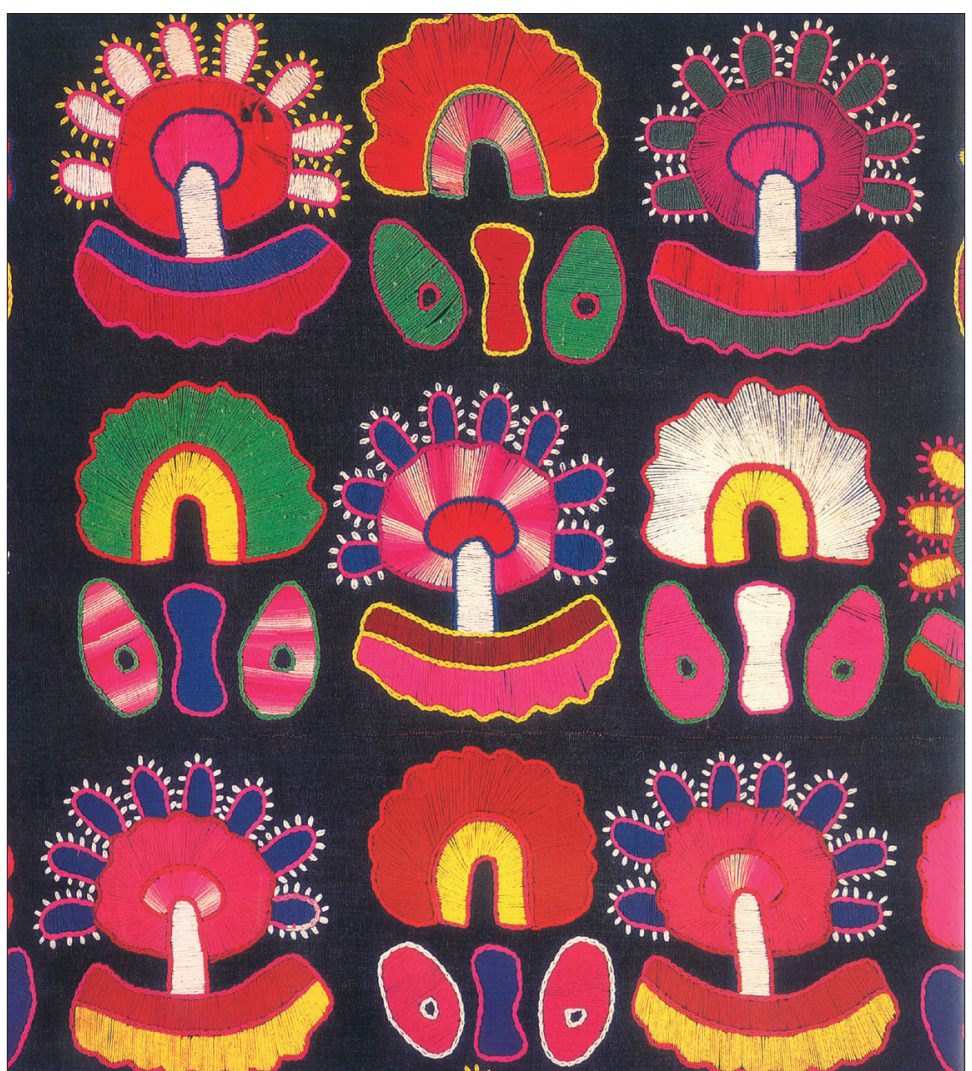

Figure 14. Mushrooms on a wedding bed cover. Slavonia, Croatia (Toldi 1999: 59).

In another wedding context, a mushroom appears on a wedding bed cover called a ponjavac from Slavonia, the eastern region of Croatia. We can see that mushrooms represent the sexual act, with mushroom stalks and caps symbolizing male and female genitals in the act of intercourse (Fig. 14). The mushroom cap clearly symbolizes the female genitalia.

Another clear example of a mushroom representing a vagina can be found in verses recorded in a village near Slavonski Brod in eastern Croatia (Toldi 1999: 45):

Da znaš mili šta imam pod krili!? Milo janje, lipo eklovanje.

Turi ruku, pa ćeš nać pečurku.
If you only knew, my dear, what I have under my lap!?

Gentle lamb, pretty little lacework, Push your hand in, and you'll find a mushroom. 
The $b a b a$ and the mushroom in the wedding skit "Baba Went Mushroom Picking", like the triangles on traditional costumes called žabica (little frog) that were introduced above, embody the same thing, female genitalia, and therefore fertility, a highly desirable attribute for newlyweds, particularly emphasized in various ways during this wedding ritual scenario (cf. Vince Pallua 2013). If we now connect the symbolism of the frog, the $b a b a$ and the mushroom with the ritual wedding skit "Baba Went Mushroom Picking", we can compare it to the already mentioned customary practice in the Yaroslavl province in Russia where, in order to get married, spinsters had to find a frog and after squatting and jumping like a frog had to sit on it with their naked bottom (Gura 2005: 283). In fact, a similar tradition exists among the southern Slavs - women have to sit on a wet rock called $b a b a^{18}$ when they want to get pregnant.

The folkloristic material I have analysed shows the intertwining of the three elements also indicated in the etymological triplet. The examples described above demonstrate the similar symbolism of the baba and the mushroom and are closely connected with the frog. Therefore, not only the linguistic/etymological but also the folkloristic data point to the unity of the items in the triplet: toads - witches / babas - mushrooms. As shown in the paper, these three "wet" items symbolize female sexual organs, fertility, and renewal.

\section{THE NAMES FOR FROGS}

It is very common among Southern Slavs that children are not allowed to call a frog by its usual term $\check{z} a b a$. Instead, they have to call it baba: "Baba is a euphemism for a frog. Children who have a mother should never say žaba, but baba, otherwise their mother would soon die" (Đorđevic 1958: 195). ${ }^{19}$ The vagina is considered a symbol of the frog and an entrance to the other world as well. Therefore the word $\check{z} a b a$ is taboo since its utterance would cause the mother's death. ${ }^{20}$ On the other hand, this might be correlated with the importance of avoiding the direct utterance of the names of gods (or goddesses) in many traditional cultures, which indicates the possibility of the former high divine status attributed to the frog. ${ }^{21}$ Could this admonition also be connected with the frog and its former image as the primeval mother / frog-goddess? ${ }^{22}$

Some of the words I found for frogs are quite interesting: "Female ghosts called boginke (goddesses) and čudožene (miracle-women), who like to exchange small children, can also look like frogs" (Gura 2005: 285-286); the European tree frog (hyla arborea), also known as "God's frog", is the most well-known type of frog in our country, which is why it has so many names. It is called bogina (goddess), kraljica (queen), kraljevčica (princess), kraljeva žabica (king's frog), 
kraljeva žabička (king's frog), zelenjara (green frog), kišnjara (rain frog), kišovica (rain frog), gatalinka (fortune teller), gatalinčica (fortune teller), katoličanka (Catholic frog), reglica (queen), krekavica (croaker), zelena žabica (small green frog), and even vračara (spell caster), because frogs were used for casting spells (Hirtz 1896: 23-24).

There are quite a few examples that illustrate the echoing of a remote depth connected with frogs up until the present day. As late as the twentieth century, people in Lithuania would erect wooden sepulchral monuments in the shape of a toad, whose heads were sometimes a sprouting lily, a symbol of regeneration (Bračko 2012: 117; Gimbutas 2001: 254), like the frog itself. "The toads were sometimes good protectors of homes, they lived in huts and were fed with milk. They were shy, quiet and good. People believed that such toads were the incarnation of the soul of those deceased from that home or ghosts" (Bračko 2012: 123). "A home frog is respected, especially if it resides under the doorstep, with its manistic meaning drawn on the basis of the frog representing an ancestor" (Kulišić \& Petrović \& Pantelić 1970: 120); "Frogs are often thought to be Titans or that Titans reside in them, or that they are a certain female saint" (Đorđević 1958: 200-201).

\section{THE FROG AND THE VIRGIN MARY}

We have seen that the sexual connotations and love magic so often associated with the frog are connected with its wetness attributes, and hence with the symbolism of fertility, life giving, renewal of life, regeneration, etc., that we have been following so far. However, the frog plays another quite important role, as the protector of water springs. This can be well illustrated by a legend from Čakovec in Međimurje, the northernmost county of Croatia. In the seventeenth century, the highest Croatian noblemen Šubic and Zrinjski bravely protected their feudal holdings, and at the same time all of Europe, from the Ottoman invasions. The following legend ${ }^{23}$ tells us about the lands granted to these noble families by the king in gratitude for their achievements and military accomplishments, all thanks to a poor young girl who managed to kill a giant frog with a ruby in its forehead. The giant frog was the protector of drinking water sources, surrounded by wetlands. At the spot where the frog was killed, water suddenly jetted out, and a well was built allowing for the construction of the castle and the life around it.

Before the construction of the palace could begin, a water well had to be dug. They dug and dug, but all they could find around them was dirty, muddy, filthy water! In the place of the future well, below a rock, they saw 
a huge green frog with bulging eyes and a big precious stone, a ruby, that shone on its forehead. It was a magical frog that guarded the water! It could be killed only by a virgin. They brought a girl from the surrounding area, dressed in a white gown, with a garland of flowers on her head. There was a whole ritual for the performance of this act. With a dagger in her hand, the girl slowly approached the frog, and when she was close enough, she stopped and readily swung with a steady arm and stabbed the frog in its heart. At that moment, pure and crystal-clear water erupted from the ground, and its invigorating taste delighted all those present. The girl was richly rewarded. (Kalšan 2011: 33-34)

This folk tale reminds us of numerous Christian narratives about the ritual murder of a mythical animal (a snake or a dragon) as the precondition for the liberating of waters. The seventeenth-century legend from northern Croatia cited above is interesting in another context as well, as it reminds us of Christian legends about healing water sources around which altars were built, with churches dedicated to the Virgin Mary erected above them. By killing a giant frog ${ }^{24}$ the poor girl enabled the release of clean drinking water, bringing life to the palace. In the same way, the Christian Virgin Mary appears as her substitute, enabling the opening of healing wells. In the reinterpretation of old religious images after Christianization, the mythical frog, as the protector of mothers and newborns, was often closely associated with the Virgin Mary, who was also the protector of barren women.

We can all recall the well-known fairy tale "Sleeping Beauty", in which the frog announces to the queen, while she is bathing, that her desperate wish to have a child would be granted and that she would become a mother within a year. "In Germany up to the 20th century, women suffering from uterine problems presented images of toads to the Virgin Mary" (Gimbutas 2001 [1989]: 255). As already mentioned, wax frog votives are still being sold and brought to St. Mary's Church in Marija Bistrica, a well-known Marian sanctuary, but today as a votive for the overall health of the whole family. ${ }^{25}$

Frogs were not considered poisonous only during the period between the Assumption and the Birth of St. Mary (from 15 August to 8 September) and were then burnt and used as a powder against various diseases (Hiller 1989). This folk belief shows that during this particular interval of time the frog is not considered ugly and poisonous. This period coincides with the most important Marian feast days.

The connection between the frog and the Virgin Mary illustrates the longevity of the symbolism of the frog. More importantly, this connection points to the blending of two images - pre-Christian and Christian - that we can see in a Bavarian votive (Fig. 15) dating from the nineteenth century. Therefore, 
we should not be surprised to see the frog (with a human vulva on its back symbolising a regenerative force) and the Virgin Mary placed right next to each other in a painting on a votive tablet from 1811 in Bavaria, southern Germany.
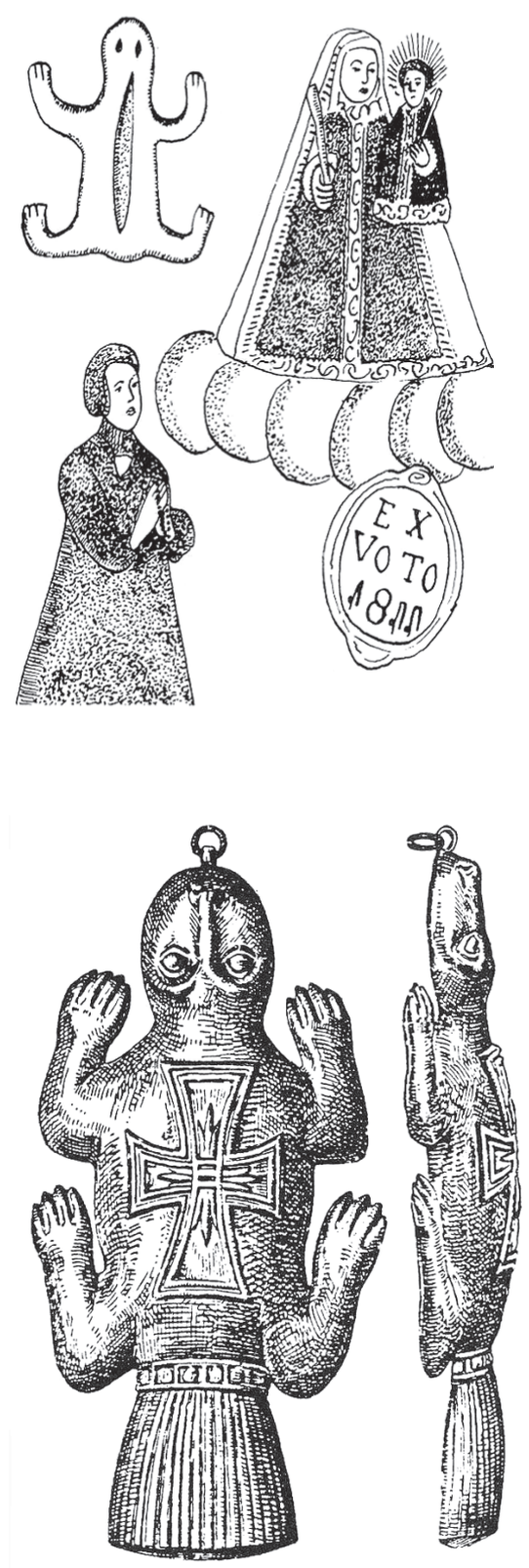

Figure 15. Ex voto / Votive tablet - frog with vulva on its back next to the Virgin Mary. Bavaria, Germany, 1811

(Gimbutas 2001 [1989]: 254).

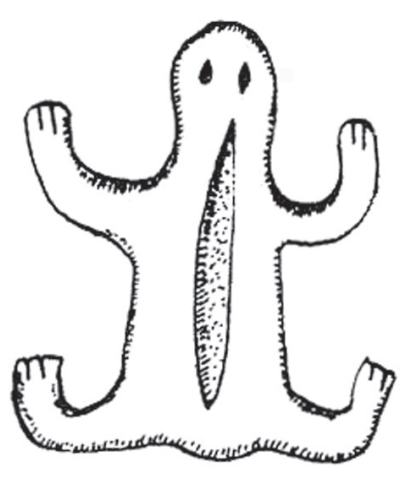

Figure 16. Silver ex-voto, frog with a human face, late nineteenth century. Andechs Monastery, Upper Bavaria, Germany (Gimbutas 2001 [1989]: 254). 
The curious examples above show two votives in the shape of a frog: one with a vulva on its back ${ }^{26}$ (Fig. 15) and one with a cross in the same place (Fig. 16). ${ }^{27}$ The silver nineteenth-century votive frog with a human face and a cross (instead of a vulva) on its back, also from Bavaria (Fig. 16), reflects the frog-woman with a goddess-vulva association - the great regeneratrix.

\section{CONCLUSION}

After discussing the rich symbolism of the frog, I have come back to the very beginning of the paper where I emphasized the "wet" attributes connected with frogs, with wetness meaning fertility, fecundity, renewal of life, regeneration, the frog as a symbol of the womb, protector of mothers and newborns, and protector of water springs. Throughout the paper, past but also contemporary imagery, legends, narratives, fairy-tales, and the folkloristic, mythical, ethnological, archaeological and linguistic aspects of the frog and its symbolism have been identified and discussed.

Numerous testimonies, some of which are perceived in this light for the first time, have shown that the frog itself was considered as a procreative organ. The Croatian and Czech ritual "frog dances", performed by married couples in secrecy, present an obvious imitation of the sexual act, symbolizing and evoking the fecundity of the annual agricultural cycle as well as the overall fertility of the fields, the cattle, and also the people of the village. Compared with these Slavic ritual frog dances, the frog-womb votives offered as gifts by infertile women have the same purpose - encouraging procreation and fertility.

The piece of cloth inserted into the national costume in two regions of Croatia, Istria and Slavonia - either into the long dress or under the armpit of the shirt - lead in the same direction. That is, they both are triangular and are called a žabica (small frog). It has been shown that the same diminutive word $\check{z}$ abica indicates female genitals in the local Istrian phrase žabicu driti, to break a small frog, as well as the triangular piece of cloth inserted into the bottom part of the dress called rubina, in the shape of a double triangle. The $\check{z} a b i c a$ as an ethnological element has been associated with triangles engraved on numerous prehistoric female statues where they also represent female genitals. In short, žabica in the folkloristic examples has been identified as a synonym for the female genitals, as is the frog itself.

We have seen that the sexual connotations so often assigned to the frog, as well as love magic, are connected with its wetness attributes and therefore with the symbolism of fertility, life giving, renewal of life, regeneration, etc., that I have been following throughout the paper. That is, "wet" attributes are 
connected not only with frogs, but with two other folkloristic items as well - the baba and the mushroom. The folkloristic triplet toads - babas - mushrooms discussed here is an additional proof of the original analogous etymological triplet toads - witches - mushrooms, with bau or bo roots in some European languages, as presented by Gimbutas. The three folkloristic elements, with wetness as a precondition for fertility, symbolise female genitals, therefore fertility, fecundity, and renewal.

The different words for frogs granted the frog a very high status. The majestic position of the frog is recognizable by the enigmatic words used for frogs, fraught with spirituality and divinity - ghosts, titans, ancestors, čudožene (miraclewomen), female saints, reglice/kraljice (queens), and boginke / bogine (goddesses). It is also reflected in the fairy-tale about žabica kraljica (a small frog queen), in which a frog, who is also a beautiful girl, becomes a queen and acquires high status in this legend, just as the words for frogs also reveal: kraljica, reglica (queen), but even more bogina and boginka (goddess).

In Christianity, the image of the frog was replaced by the image of the Virgin Mary. Again, we should not be surprised by the proximity of the frog (with a human vulva on its back as a symbol of the regenerative force) and the Virgin Mary presented right next to each other on the Bavarian votive tablet from 1811 or by the wax frog-shaped votives brought to one of the most famous Croatian Marian pilgrimage sites, Marija Bistrica. The votives provide us with material proof that vividly points to the intertwining of the frog and the Virgin Mary, and even more so, as shown in this paper, to the longevity of the frog as a symbol of fertility, fecundity, female genitals, procreation, and regeneration up until the present day. The two parallel worlds are shown standing together in an interesting syncretism of the pre-Christian and Christian worlds.

\section{NOTES}

1 Although one of the leading American mythologists, Joseph Campbell, compared the importance of the scientific achievements of this Lithuanian-American archaeologist and anthropologist to that of Champollion's decipherment of the Rosetta Stone (Campbell 2001 [1989]: xiii), some of her statements have been greatly challenged.

2 Although members of the same order, Anura, frogs and toads are different groups of amphibians. Nevertheless, they are used almost interchangeably in myth and legend. As Sax points out, frog and toad, as the terms are often used, seem almost like words for different aspects of a single creature (Sax 2001: 123). 
3 In her PhD dissertation about votives, Mirela Hrovatin stresses the demonic aspect of the frog, considered to be influenced by Christianity (2015: 136).

4 When I visited licitar shops in Marija Bistrica on 31 December 2018, I saw wax votives of houses, legs, eyes, pigs, hens, etc., but I could not find an ex-voto of a frog, though some people claim they are still being sold.

5 Due to its particularity and special value, the description of this ritual dance is given here in extenso. It can be seen in the Croatian TV show Pučka intima (The Common People's Intimacy).

${ }^{6}$ I would like to thank my colleague Jiři Woitsch for informing me about the Czech dances in the entry in the Czech ethnological encyclopaedia (Tyllner et al. 2007).

7 Since Ribarić's PhD thesis was written in Vienna in German, the explanation of the Croatian phrase is also given in German.

8 I should also mention that in colloquial Slovene, as I was informed by Mirjam Mencej, žabica means a lock with a "phallus-like" key.

9 Writing about modrne (blue dresses) in the Barban region in Istria, Barbara Ban quoted the work of Radauš Ribarić (1997: 121) and stressed that a modrna klinarica (wedge-shaped blue dress) also has an insertion called žabica (Ban 2019).

${ }^{10} \mathrm{~A} \check{z}$ abica under the armpit is also mentioned in Varoš near Slavonski Brod, and also in Slavonia (Lukić 1919: 83).

${ }^{11} \mathrm{Cf}$. endnote 2.

${ }^{12}$ Not knowing about this etymological connection, I published three articles about the $b a b a$, a mythological character similar to a witch (Vince Pallua 1996; 2013; 2018). I also published an article about the mythological symbolism of mushrooms (Vince Pallua 2013). Finally, the frog, which is in the focus of my present research, is the third item in this etymological and mythological triplet.

${ }^{13}$ Katja Hrobat Virloget dedicated a great deal of her research to the phenomenon of babas, especially in the Karst region in Slovenia. Furthermore, with the help of D. E., a student from Venice, in 2013, she was able to identify the presence of babas outside of the Slavic world, i.e., in Italian and French folklore.

${ }^{14}$ For the second figurative discovery of the $b a b a$ cf. Vince Pallua 2018.

15 The Neolithic Sumerian goddess Bau, also called Baba (Gimbutas 1999: 28), raises her skirt in an ancient ritual while displaying her vulva.

${ }^{16}$ Mushrooms, which are 95 percent water, draw moisture from the soil and grow quickly, from a few hours to 14 days, hence the expression "you are growing like a mushroom after the rain".

${ }^{17}$ It should be added that a festive ritual bread called baba is baked for baptismal celebrations and, like the aforementioned babas, it also has to be kissed. 
18 There is a testimony from the valley of the Soča River in Slovenia about the healing power of the rock Babja rit (Baba's arse) - people would sit on the rock due to its healing qualities. Near this rock were two other round rocks associated with fecundity (Hrobat 2010: 213).

${ }^{19}$ In a future article, I will address the very intriguing correlation between $\check{z} a b a$ and $b a b a$ (not only phonetically), including a mushroom that also shares similar connotations with these two terms.

${ }^{20}$ I would like to thank Mirjam Mencej for this observation.

${ }^{21}$ As a water goddess, the Egyptian goddess of childbirth, creation, and grain germination was depicted as a frog or a woman with the head of a frog betraying her connection with water (Seawright 2001). The goddess Sheela na gig is "none other than the descendant of the ancient frog or toad goddess, the birth giver and re-generatrix inherited from the Neolithic (Gimbutas 1999: 29, text accompanying figure 20).

${ }^{22}$ While studying the formal and symbolic structure of female headgear in the broader Dubrovnik region in Croatia (Konavle, Mljet Island, etc.), Ivica Kipre noticed motifs of frogs on them. He also gave some parallels to the Russian headgear (from Arhangelsk province) called soroka-kerčef with the motif of a little frog, or archetipal mother (Kipre 2012: 207, 224).

${ }^{23}$ I would like to thank my colleague Lidija Bajuk for informing me about this legend.

${ }^{24}$ In another Slavic part of the world (Czestochowa, Poland) the bond between the female character, water, and a giant frog is shown in the quote as well: "The wife of a water-ghost can appear as a giant frog" (Gura 2005: 286).

${ }^{25}$ Cf. Fig. 2.

${ }^{26} \mathrm{Cf}$. also German wax toad votive with a vulva on its back (Fig. 1).

${ }^{27}$ There is also a cross on the back of the frog on a wooden mould for a votive of a frog from Križevci, northern Croatia, mid-nineteenth century (Fig. 5). 


\section{REFERENCES}

Alinei, Mario 1988. Slavic Baba and Other 'Old Women' in European Dialects: A Semantic Comparison. In: Basaj Mieczysław \& Szymczak Mieczysław (eds.) Wokot języka: rozprawy i studia pośw. pamieçi profesora Mieczystawa Szymczaka. Wrocław: Zakład Narodowy im. Ossolińskich, pp. 41-51.

Ban, Barbara 2019. O Nošnjama. [About National Costumes.] Barban.hr. Available at http://barban.hr/kud-barban/o-nosnjama/, last accessed on 6 November 2019.

Bračko, Mirjana 2012. Krastače žabe u litavskoj književnoj etnotradiciji. [Toads in Lithuanian Literary Ethnotradition.] In: Suzana Marjanić \& Antonija Zaradija Kiš (eds.) Književna životinja: Kulturni bestijarij II. dio. [Literary Beast: Cultural Bestiary Part II.] Zagreb: Hrvatska sveučilišna naklada, Biblioteka etnografija, Institut za enologiju i folkloristiku, pp. 115-137.

Campbell, Joseph 2001 [1989]. Foreword. In: Marija Gimbutas. The Language of the Goddess: Unearthing the Hidden Symbols of Western Civilization. New York: Thames \& Hudson, p. xiii.

Catalogue 2013 = Vjera, ufanje $i$ ljubav. [Faith, Hope and Love.] Varaždin: Gradski muzej Varaždin. Available at https://issuu.com/obla/docs/vjera_i, last accessed on 6 November 2019.

Čulinović-Konstantinović, Vesna 1989. Aždajkinja iz Manite drage: Običaji, vjerovanja, magija, liječenja. [Dragoness from Manita Draga: Customs, Beliefs, Magic, Healing.] Split: Logos.

Devereux, Georges 1990. Bauba - mitska vulva. [Bauba - The Mythical Vulva.] Transl. by Radmila Zdjelar. Zagreb: August Cesarec.

Đorđević, Tihomir R. 1958. Priroda u verovanju i predanju našega naroda 2. [Nature in Belief and Legend of Our People.] Vol. 2. Belgrade: Naučno delo.

Gimbutas, Marija 1999. The Living Goddesses. Berkeley: University of California Press.

Gimbutas, Marija 2001 [1989]. The Language of the Goddess: Unearthing the Hidden Symbols of Western Civilization. New York: Thames \& Hudson.

Grdinić, Vladimir \& Dugac, Željko \& Biškupić Bašić, Iris 2007. Od vrta do neba: ljekovito bilje i zavjetni darovi za zdravlje. [From Garden to Heaven: Medical Plants and Votive Offerings for Health.] Transl. by Valentina Kolar. Gornja Stubica: Muzeji Hrvatskog zagorja, Muzej seljačkih buna.

Gura, Aleksandar V. 2005. Simbolika životinja u slovenskoj narodnoj tradiciji. [The Symbolism of Animals in Slavic Folk Tradition.] Belgrade: Globosino.

Hiller, Helmut 1989. Žaba. [The Frog.] In: Helmut Hiller. Sve o praznovjerju. [Everything about Superstition.] Transl. by Tamara Marčetić. Zagreb: Grafički zavod Hrvatske. Available at https://kupdf.net/download/helmut-hiller-sve-o-praznovj erju_5afe16e1e2b6f5a4195a1210_pdf, last accessed on 6 November 2019.

Hirtz, Dragutin 1896. Što priča naš narod o nekim životinjama. [What Our Nation Narrates about Some Animals.] In: Ivan Milčetić (ed.) Zbornik za narodni život i običaje Južnih Slavena, Svezak 1. [Almanac of Folk Life and Customs of Southern Slavs, Vol. 1.] Zagreb: Jugoslavenska akademija znanosti i umjetnosti, pp. 1-26. Available at https://archive.org/details/zbornikzanarodn00umjegoog/page/n4, last accessed on 5 November 2019. 
Hranjec, Stjepan 2011. Međimurski narodni običaji. [Folk Customs of Međimurje.] Čakovec: Matica hrvatska, Ogranak Čakovec: "Zrinski”: Zajednica Hrvatskih kulturno-umjetničkih udruga Međimurske županije.

Hrobat, Katja 2010. Ko Baba dvigne krilo: Prostor in čas v folklori Krasa. [When Baba Lifts Her Skirt: Space and Time in the Folklore of the Karst.] Ljubljana: Znanstvena založba Filozofske fakultete Univerze v Ljubljani.

Hrovatin, Mirela 2015. Kulturnoantropološki pristup zavjetu u izvaninstitucijskoj osobnoj pobožnosti. [A Cultural-Anthropological Approach to Vows in Noninstitutional Personal Religiosity.] Diss. (PhD Thesis.) Filozofski fakultet Sveučilišta u Zagrebu. Kalšan, Vesna 2011. Čakovečke legende. [Legends of Čakovec.] Čakovec: Self-publication. Kipre, Ivica 2012. Formalna i simbolična struktura konavoskoga ženskog oglavlja. [The Formal and Symbolic Structure of the Konavle Woman's Headgear.] In: Tonko Marunčić \& Vedrana Gjukić Bender \& Pavica Vilać \& Liljana Kovačić (eds.) Zbornik Dubrovačkih muzeja II. [Proceedings of the Museums of Dubrovnik II.] Dubrovnik: Dubrovački muzeji, pp. 207-229. Available at https://www.academia. edu/32244832/Dubrovacki_muzeji_-_Zbornik_1.pdf, last accessed on 6 November 2019.

Kuğutjak, Mykola 2018. Simboli vječnosti ili sakralni znakovi hrama. [Symbols of Eternity or the Sacred Signs of the Temple.] In: Jevgenij Paščenko \& Tetyana Fuderer (eds.) Kamena svetišta ukrajinskih Karpata (prijevodi s ukrajinskoga). Knjižnica Ucrainia Croatica, knj. 16. Zagreb: Katedra za ukrajinski jezik i književnost Filozofskog fakulteta Sveučilišta u Zagrebu, Udruga "Hrvatskoukrajinska suradnja”, pp. 143-155.

Kulišić, Špiro \& Petrović, Petar Ž. \& Pantelić, Nikola 1970. Srpski mitološki rečnik. [Serbian Mythological Dictionary.] Beograd: Nolit.

Kus-Nikolajev, Mirko 1928. Votivi nerotkinja. [The Votives of Barren Women.] Etnolog (Ljubljana), Vol. 2, pp. 36-45. Available at https://www.dlib.si/details/ URN:NBN:SI:doc-MRIJIKRT, last accessed on 6 November 2019.

Laskow, Sarah 2017. The Tale of the Toad and The Bearded Female Saint. Atlas Obscura, 10 May. Available at https://www.atlasobscura.com/articles/toad-votives-religionmedieval-saints, last accessed on 6 November 2019.

Lovrenčević, Zvonko 1967. Bilje kojim se gata i vrača u okolici Bjelovara. [Herbs for Telling Fortune and Soothysaying of the Surroundings of Bjelovar.] In: Branimir Gušić (ed.) Zbornik za narodni život i običaje južnih Slavena, knj. 43. [Almanac of Folk Life and Customs of Southern Slavs, Vol. 43.] Zagreb: Jugoslavenska akademija znanosti i umjetnosti, pp. 135-159. Available at http://dizbi.hazu.hr/ object/view/8Ak3cG6kMA, last accessed on 6 November 2019.

Lukić, Luka 1919. Varoš. [Varoš.] In: Dragutin Boranić (ed.) Zbornik za narodni život $i$ običaje južnih Slavena, knj. 24. [Almanac of Folk Life and Customs of Southern Slavs, Vol. 29.] Zagreb: Jugoslavenska akademija znanosti i umjetnosti, pp. 32238.

Lyle, Emily 2012. Ten Gods: A New Approach to Defining the Mythological Structures of the Indo-Europeans. Newcastle upon Tyne: Cambridge Scholars Publishing. 
Mencej, Mirjam 2015. Origins of Witchcraft Accusations. Studia Mythologica Slavica, No. 18, pp.111-130. Available at http://sms.zrc-sazu.si/pdf/18/07_sms_18_Mencej. pdf, last accessed on 5 November 2019.

Pizza, Giovanni 2006. Toads. In: Richard M. Golden (ed.) Encyclopedia of Witchcraft: The Western Tradition. Vol IV; Q-Z. Santa Barbara \& Denver \& Oxford: ABCCLIO, pp. 1123-1125. Available at https://astridpriscilladion.files.wordpress. com/2019/05/encyclopedia-of-witchcraft.pdf, last accessed on 6 November 2019.

Radauš Ribarić, Jelka 1997. Ženska narodna nošnja u Istri. [Female National Costume in Istria.] Zagreb \& Pazin: Institut za etnologiju i folkloristiku; IKD Juraj Dobrila; IKD Josip Turčinović.

Ribarić, Josip 2002. O istarskim dijalektima: Razmještaj južnoslavenskih dijalekata na poluotoku Istri s opisom vodičkog govora. [On Istrian Dialects: Topology of South-Slavic Dialects on the Istrian Peninsula with the Description of the Vodice Dialect.] Pazin: IKD Josip Turčinović.

Sax, Boria 1990. The Frog King: On Legends, Fables, Fairy Tales, and Anecdotes of Animals. New York: Pace University Press.

Sax, Boria 2001. The Mythical Zoo: An Encyclopedia of Animals in World Myth, Legend, and Literature. Santa Barbara \& Denver \& Oxford: ABC-CLIO.

Seawright, Caroline 2012 [2001]. Heqet, Frog-Headed Goddess of Childbirth. Thekeep. org, 29 November. Available at http://www.thekeep.org/ kunoichi/kunoichi/ themestream/heqet.html, last accessed on 6 November 2019.

Seler, Eduard 1910. Die Tierbilder der Mexikanischen und der Maya-Handschriften: Reptilien und Lurche. Zeitschrift Für Ethnologie, Vol. 42, No. 1, pp. 31-97. Available at https://www.jstor.org/stable/i23030681, last accessed on 6 November 2019.

Španiček, Žarko 2010. Bizovačka narodna nošnja. [National Costume of Bizovac.] Bizovac: Ogranak Matice hrvatske Bizovac; KUD Bizovac.

Toldi, Zvonimir 1999. Dvoje leglo troje osvanilo: [monografija krpanih ponjava]: magijski simboli plodnosti, sreće i zaštite od uroka. [Two Went to Bed, Three Came Out: Magic Symbols of Fertility, Fortune and Defence against Calamity.] Slavonski Brod: Muzej Brodskog Posavlja.

Tyllner, Lubomír \& Brouček, Stanislav \& Jeřábek, Richard \& Holý, Dušan \& Hubinger, Václav \& Petráňová, Lydia \& Traxler, Jiří \& Válka, Miroslav \& Vařeka, Josef (eds.) 2007. Lidová kultura: národopisná encyklopedie Čech, Moravy a Slezska. Sv. 3: $O$ - Ž. [Folk Culture: Ethnographical Encyclopaedia of Czech, Moravia, and Slezka. Vol. 3: O - Ž.] Prague: Mladá Fronta.

Vince Pallua, Jelka 1996. History and Legend in Stone: To Kiss the Baba. Studia ethnologica Croatica, Vol. 7/8, No. 1, pp. 281-290. Available at https://hrcak. srce.hr/index.php?show=toc\&id_broj=4687, last accessed on 5 November 2019.

Vince Pallua, Jelka 2013. "Baba gljive brala": Međimurska svadbena dramska igra kao izvor i put do svetosti praslavenskoga obreda. [Baba Went Picking Mushrooms: A Wedding Skit From Medimurje as a Source and a Path to the Sacredness of Proto-Slavic Wedding Rituals.] Studia ethnologica Croatica, Vol. 25, No. 1, pp. 231-252. Available at https://hrcak.srce.hr/index.php?show=clanak\&id_ clanak_jezik=165364, last accessed on 6 November 2019 . 
Vince Pallua, Jelka 2018. A Newly Discovered Figurative Representation of the Mythical Baba - 'Old Baba Vukoša' in St. Mary's Church of Gračišce in Istria. In: Juraj Belaj \& Marijana Belaj \& Siniša Krznar \& Tajana Sekelj Ivančan \& Tatjana Tkalčec (eds.) Sacralization of Landscape and Sacred Places: Proceedings of the 3rd International Scientific Conference of Medieval Archeology of the Institute of Archeology. Zagreb, 2nd and 3rd June 2016. Zbornik Instituta za arheologiju, Vol. 10. Zagreb: Institut za arheologiju, pp. 105-115. Available at https://www. academia.edu/38046428/, last accessed on 6 November 2019.

Vrkić, Jozo (ed.) 1991. Vražja družba: Hrvatske bajke i predaje o vilama, vješticama, vrazima, vukodlacima. [A Diabolic Gang: Croatian Fairy-tales and Legends About Fairies, Witches, Devils, Vampires.] Zagreb: Self-publication.

Jelka Vince Pallua, $\mathrm{PhD}$, is full professor of ethnology and cultural anthropology and scientific advisor at the Institute of Social Sciences Ivo Pilar, Croatia. Her areas of scientific interest include Croatian and Slavic ethnography; history of Croatian ethnology in the European context; mythology, legends and traditions; position of women in traditional cultures; Mediterranean studies and traditional cultures of the Adriatic; Morovlachs and the phenomenon of morlachism; Croats in Italy and Italians in Croatia. jelka.vince@gmail.com 